\title{
Yield in tomato under two water depths and plastic mulching
}

Anita Cristina Costa da Silva ${ }^{1} \oplus$, João Marcelo Silva do Nascimento ${ }^{2} \odot$, Adriano Valentim Diotto $^{1} \oplus$, Luiz Antonio Lima ${ }^{1} \odot$, Mayra Carolina de Oliveira ${ }^{1}[0$

\footnotetext{
1 Universidade Federal de Lavras, Departamento de Engenharia, Laboratório de Hidráulica, Lavras, MG, Brazil. E-mail: anitacsilva@hotmail.com; adriano.diotto@gmail.com; lalimaufla@yahoo.com; mayragepfor@yahoo.com.br

${ }^{2}$ Fundação Universidade Federal de Rondônia, Campus Rolim de Moura, Rolim Moura, RO, Brazil. E-mail: jmarcelo.unir@gmail.com
}

ABSTRACT: The search for sustainable agriculture is a reality that aims saving water and agricultural inputs to obtain greater productivity. Some techniques can be used for this purpose, such as drip irrigation and the plastic mulch of the soil. Thus, the aim of this study was to verify the effects of plastic mulch under two water depths on the productive characteristics of a commercial tomato field. The employed experimental design was the completely randomized in a $2 \times 2$ factorial. The sources of variation were two types of soil cover (with and without plastic mulch) and two water depths (164 mm and $188 \mathrm{~mm}$ ) with nine replicates. Plant height and water use efficiency were not influenced by soil mulch or water depth variation. Soil with plastic mulch provided a lower mean fruit mass (108.32 $\mathrm{g}$ fruit $\left.{ }^{-1}\right)$, however, with a higher number of fruits per plant (70), which contributed to a higher commercial yield $\left(58.42 \mathrm{t} \mathrm{ha}^{-1}\right)$. The highest total yield $\left(64.08 \mathrm{t} \mathrm{ha}^{-1}\right)$ was obtained in the soil with plastic mulch under the water depth of 188 $\mathrm{mm}$. The use of plastic mulch associated with a water depth of $188 \mathrm{~mm}$ provided an increase in tomato yield.

Key words: irrigated horticulture; irrigation management; Solanum lycopersicum L.; yield

\section{Produtividade em tomateiro sob duas lâminas de irrigação e mulching}

RESUMO: A busca pela obtenção de uma agricultura sustentável visa a economia de água e insumos agrícolas para obtenção de maiores produtividades. Para tal, algumas técnicas podem ser utilizadas, como a irrigação por gotejamento e a cobertura plástica do solo. Assim, objetivou-se com este trabalho verificar os efeitos da cobertura plástica e duas lâminas de irrigação sobre as características produtivas do tomateiro em lavoura comercial. 0 delineamento experimental utilizado inteiramente casualizado, em esquema fatorial $2 \times 2$. As fontes de variação foram dois tipos de cobertura do solo (sem e com cobertura plástica) e duas lâminas de irrigação $(164 \mathrm{~mm}$ e $188 \mathrm{~mm}$ ) com nove repetições. A altura das plantas e eficiência de uso de água não foram influenciadas pela cobertura do solo nem pela variação das lâminas. 0 solo com cobertura proporcionou uma menor massa média de frutos $\left(108,32 \mathrm{~g}_{\text {fruto }}^{-1}\right)$, mas com um número maior de frutos por planta (70) o que contribuiu para uma maior produtividade comercial $\left(58,42 \mathrm{t} \mathrm{ha}^{-1}\right)$. A maior produtividade total $\left(64,08 \mathrm{t} \mathrm{ha}^{-1}\right)$ foi obtida no solo com cobertura plástica sob a lâmina de $188 \mathrm{~mm}$. O uso de cobertura plástica associado a lâmina de $188 \mathrm{~mm}$ proporcionou aumento na produtividade do tomateiro.

Palavras-chave: horticultura irrigada; manejo de irrigação; Solanum lycopersicum L.; produtividade 


\section{Introduction}

Higher productivity can be achieved through sustainable agriculture and aims to save water and agricultural inputs. Some techniques can be used for this purpose, including drip irrigation and the soil plastic mulching. The advantages of drip irrigation comprise water conservation and reduction of harmful impacts to water use due to the potential for high application efficiency, improved crop quality and yield, and ease of agrochemicals application (Frizzone et al., 2012). The plastic mulches have been increasingly used in the vegetable productions due to several advantages, such as the reduction of both soil surface water evaporation and weed incidence, irrigation water saving, and production increase (Branco et al., 2010; Yuri et al., 2012; Almeida et al., 2015).

The tomato is the second most produced vegetable worldwide. According to FAO (2017), world tomato production in 2014 was over 170 million tons. Brazil is among the ten largest producers, with tomato grown in most states, and most of the national crop being destined for the salad tomato. According to the systematic agricultural production survey, in 2015, Brazilian production of tomatoes was $4,187,729$ tons. The State of Minas Gerais is the third producer (20\%), totaling 715,890 tons (IBGE, 2016).

The soil mulch with plastic film limits the development of weeds, promotes insect repellency, and can reduce soil thermal amplitude and nutrient leaching, thus increasing water and nutrient plant availability and maintaining a higher level of moisture on the top layer (Sampaio \& Araújo, 2001).

The use of drip irrigation in tomato plants has indicated water savings of up to $30 \%$ with an increase in productivity of up to $40 \%$ and improvement in fruit quality (Marouelli \& Silva, 2002). Some research shows effects of soil plastic mulch on the yield of some vegetables. The soil mulch with polyethylene films increased the yield of tomato (Branco et al., 2010; Campagnol et al., 2014), strawberry (Yuri et al., 2012), cabbage (Branco et al., 2010), and melon (Morais et al., 2008). In Texas, Elsayed-Farag et al. (2018) cite that the highest yields in tomato varieties were found in the plants grown in the soil with plastic cover, with the white plastic having higher productivity, followed by the black and the soil without cover, both with the lower yields.

Tomato has high water requirement and to achieve efficiency in the water use in its cultivation implies positive effects in economic terms and environmental effects. Monte et al. (2013) evaluated the influence of water depths $(40,60$, 80 and $120 \%$ of crop evapotranspiration) on the production of "Débora Plus" tomato fruits and found that the amount of water applied above $80 \%$ of ETc resulted in larger total production of fruits, but with the same commercial fruit production obtained in the treatments with smaller applied water depths. The water use efficiency can be affected by the use of plastic mulch. Zhang et al. (2016) obtained the highest water use efficiency when $60 \%$ ETc of the tomato was applied with drip and plastic mulch of the soil. In a study developed by Campagnol et al. (2014), the water use efficiency increased with the reduction of the water depth, being this increase more pronounced with the use of the soil mulch.

In this way, the aim of this study was to verify the effects of plastic mulch and different water depths on the yield in commercial tomato field.

\section{Material and Methods}

The experiment was conducted from June to November 2016 in a commercial tomato field, with seven sectors spread over the area of approximately 20 hectares, in the Ingaí city, MG, Brazil, at $21^{\circ} 27^{\prime} 30.9^{\prime \prime} \mathrm{S}$ and $44^{\circ} 56^{\prime} 49.7^{\prime \prime} \mathrm{W}$ and $977 \mathrm{~m}$ of altitude. The climate of the region is Cwb type according to Köppen classification, with humid summer and dry winter (Alvares et al., 2013). Precipitation during the experimental period was $220 \mathrm{~mm}$.

The soil was classified as a Red-Yellow Latosol (Soil Survey Staff, 2014) of clayey texture, cultivated with soybean in the previous year, with the chemical composition in the $0-0.20 \mathrm{~m}$ layer: $\mathrm{pH}_{\text {(water) }}=6.4, \mathrm{P}=6.2 \mathrm{mg} \cdot \mathrm{dm}^{-3}, \mathrm{~K}^{+}=166 \mathrm{mg} \cdot \mathrm{dm}^{-3}, \mathrm{Ca}^{2+}=$ $5.2 \mathrm{cmol}_{c} \cdot \mathrm{dm}^{-3}, \mathrm{Mg}=0.8 \mathrm{cmol} \cdot \mathrm{dm}^{-3}, \mathrm{Al}^{3+}=0.0 \mathrm{cmol} \cdot \mathrm{dm}^{-3}, \mathrm{H}+\mathrm{Al}$ $=2.02 \mathrm{cmol}_{\mathrm{c}} \cdot \mathrm{dm}^{-3}$, O.M. = $3.61 \mathrm{dag} \cdot \mathrm{kg}^{-1}, \mathrm{P}_{\mathrm{rem}}=11.0 \mathrm{mg} \cdot \mathrm{L}^{-1}, \mathrm{Zn}=$ $4.8 \mathrm{mg} \cdot \mathrm{dm}^{-3}, \mathrm{Fe}=39.6 \mathrm{mg} \cdot \mathrm{dm}^{-3}, \mathrm{Mn}=18.8 \mathrm{mg} \cdot \mathrm{dm}^{-3}, \mathrm{Cu}=1.0$ $\mathrm{mg} . \mathrm{dm}^{-3}, \mathrm{~B}=0.6 \mathrm{mg} \cdot \mathrm{dm}^{-3}, \mathrm{~S}=5.6 \mathrm{mg} \cdot \mathrm{dm}^{-3}$.

Fertilization was performed based on soil chemical analysis, following the recommendations for the crop. Before transplanting, $400 \mathrm{~kg} \mathrm{ha}^{-1}$ of $\mathrm{P}_{2} \mathrm{O}_{5}, 150 \mathrm{~kg} \mathrm{ha}^{-1}$ of $\mathrm{K}_{2} \mathrm{O}$ and $50 \mathrm{~kg}$ $\mathrm{ha}^{-1}$ of $\mathrm{N}$ were applied. After planting, the fertilizations were carried out daily through fertigation, according to the crop development stages. For this purpose, $131 \mathrm{~kg} \mathrm{ha}^{-1}$ of N, $235 \mathrm{~kg}$ ha ${ }^{-1}$ of $\mathrm{P}_{2} \mathrm{O}_{5}, 654 \mathrm{~kg} \mathrm{ha}^{-1}$ of $\mathrm{K}_{2} \mathrm{O}, 188 \mathrm{~kg} \mathrm{ha}^{-1}$ of $\mathrm{Ca}, 66 \mathrm{~kg} \mathrm{ha}^{-1}$ of $\mathrm{Mg}, 87 \mathrm{~kg} \mathrm{ha}^{-1}$ of $\mathrm{S}$, and $6 \mathrm{~kg} \mathrm{ha}^{-1}$ of $\mathrm{B}$ were used.

The experimental design was completely randomized in a $2 \times 2$ factorial design with two types of soil mulch (with and without plastic mulch) and two water depths (164 mm and $188 \mathrm{~mm}$ ), and nine replicates. Each plot measured $5.00 \mathrm{~m}$ in length and $0.90 \mathrm{~m}$ wide, totaling an experimental area of 162 $\mathrm{m}^{2}$, where 14 plants were transplanted and four center plants were used as a useful plant.

The irrigation system used was the drip irrigation: Netafim DripNet $^{\circledR}$ PC with flow rate of 1.6 L. $^{-1}$ every $0.50 \mathrm{~m}$ and Hydro ${ }^{\circledR}$ PC with flow rate equal to 2.2 L.h $^{-1}$ every $0.60 \mathrm{~m}$. The drip models provided different water depths, with a $164 \mathrm{~mm}$ water depth applied by Netafim and a $188 \mathrm{~mm}$ water depth applied by Hydro PC, all carried out at the end of the crop cycle.

The "Italian" tomato was used. The tomato seedlings were transplanted in double rows with spacing of $0.70 \times 0.90 \mathrm{~m}$ and the aisle between the rows were spaced $2.90 \mathrm{~m}$. In these, the drip tubes were installed under the double-sided plastic film (white/black) with the white face upwards in the treatments with mulch.

After transplanting, daily irrigations was held to ensure the seedlings establishment. Irrigation management was done according to the reading of the tensiometers installed at $0.20 \mathrm{~m}$ deep in the seven property sectors. Since it was a 
commercial field, the employees performed the tensiometer readings at 7:00 am in all sectors. The irrigation time was calculated using the mean values from the tensiometers, trying not to exceed the limit of the critical water tension in the soil $(20 \mathrm{kPa})$.

Although irrigation management was not carried out using the retention curve, it was determined, at $02.0 \mathrm{~m}$, to identify possible soil aeration problems, and it was adjusted to van Genuchten (1980) model (Equation 1).

$$
\theta=0.256+\frac{0.264}{\left[1+\left(0.657 \times\left|\Psi_{\mathrm{m}}\right|\right)^{1.351}\right]^{0.260}}
$$

where: $\theta$ - moisture based on volume, $\mathrm{cm}^{3} \mathrm{~cm}^{-3} ; \Psi_{\mathrm{m}}$ - soil matric potential, $\mathrm{kPa}$.

Plants were conducted with two stems, training and sprouting. The control of diseases and pests was done following the conventional recommendations with applications of fungicides and insecticides according to the crop needs. Harvests started 91 days after transplanting and were performed according to the physiological fruit maturity.

The following variables responses were evaluated:

- Matric potential $\left(\Psi_{\mathrm{m}}\right)$ : obtained from the tensiometer readings located at $0.20 \mathrm{~m}$ depth in each plot, expressed in $-\mathrm{kPa}$;

- Plant height: evaluated at full flowering season (66 days after transplanting) measured on the larger stem using a measuring tape. Results were expressed in meters (m).

- Total yield: resulting from the product of the mean mass of the total fruits by the number of fruits per plant and the number of plants per hectare (7,200 plants per hectare) each plot, during 24 harvests between September 19 and November 11, 2016, expressed in $\mathrm{tha}^{-1}$;

- Commercial yield: obtained by the difference between total yield and non-commercial yield; damaged fruits, including those with cracks, with blossom end rot or with insect damage were considered non-commercial, expressed in $\mathrm{t} \mathrm{ha}^{-1}$;

- Number of fruits per plant: accounted throughout harvests;

- Mean fruit mass: obtained by dividing the total fresh mass of fruit, harvested in each plot, by their respective number of fruits, throughout the harvest period, expressed in grams per fruit (g fruit ${ }^{-1}$ );

- Water use efficiency: relation between commercial yield and total volume of water applied in each treatment; expressed in $\mathrm{kg} \mathrm{m}^{-3}$.

The variables were submitted to analysis of variance and, when significant by $F$ test, the means were compared by Tukey test at the $5 \%$ probability level. Statistical analyses were performed using the software SISVAR, version 4.6 (SISVAR, Version 4.6).

\section{Results and Discussion}

There was no significant difference of plant height as a function of soil mulch and water depth variation, with mean values of $1.11 \mathrm{~m}$ (Table 1). Only one evaluation (at 66 DAT) of plant height was not enough to identify the influence of the factors in this variable. Another factor that may have caused the same height of plants is that all were cultivated with the same spacing, and usually the height of the plants is influenced when the spacing between them changes.

Some studies have also did not observe differences in plant height, such as Ngouajio et al. (2007), who evaluated cv. Mountain Spring in Michigan, USA, under black plastic film. Bogiani et al. (2008) also did not observe difference in plant height using white plastic film and soil without mulch, corroborating this very study. However, Macêdo \& Alvarenga (2005) verified that the variation of the water depths $(40,60$, 80 and $100 \%$ of $\mathrm{Kc}$ ), influenced plant height, both at 30, $60 \mathrm{e}$ 90 days after transplanting.

It was observed a significant effect of soil mulch on the mean tomato fruit mass, regardless of the applied water depth (Table 1). Plants cultivated in the soil without plastic mulch provided larger fruits, with a mean of $113.26 \mathrm{~g} \mathrm{fruit}^{-1}$. The bare soil produced fruits with higher mean mass as the plants produced less fruits, which can be explained by competition for photoassimilates available between fruits. Plants with lower fruit numbers (which occurred in treatments without soil cover) produce larger fruits and consequently, plants with a high number of fruits produce fruits with lower mass. Ngouajio et al. (2007) obtained mean fruit mass of $266.3 \mathrm{~g}$ for cv. Mountain Spring grown with black plastic film, this value greater than that obtained in this study is probably due to the variety difference. On the other hand, in a study conducted by Bogiani et al. (2008), the soil mulch with both white and black plastic did not affect the mean fruit mass of "Duradoro" tomato.

Although plants cultivated in the soil with mulch provided fruits with lower weight, the number of fruits per plant was higher than plants cultivated in the soil without mulch, which resulted in higher commercial yield under the use of plastic mulch. The use of soil cover can reduce soil water evaporation and nutrient leaching, increasing plant availability and maintaining moisture in the topsoil, thus contributing to a higher number of fruits per plant and consequently an increase in commercial yield of tomato fruits.

The applied water depth did not influence the mean fruit mass (Table 1). Results obtained in this study corroborate Campagnol et al. (2014), which studied the effect of irrigation depths and did not observe water depths effect in the mean fruit mass as well, with an mean of $106.90 \mathrm{~g} \mathrm{fruit}^{-1}$ for the "San Vito hybrid", close value to the obtained in this study. The commercial tomato for consumption "salad tomato" is valued mainly by its weight, being this an important attribute at commercial level. The standard demanded by the salad tomato fruit market, for Santa Cruz-type cultivars, is 80-200 g (Alvarenga et al., 2013). The average weight of the Italiantype tomatoes is around $140 \mathrm{~g}$, due to it being provided higher yield during the processes (Monteiro et al., 2008) .

Soil mulch influenced the number of fruits per plant (Table 1). Plants cultivated in the soil with mulch provided more 
Table 1. Summary of the analysis of variance for the plant height $(\mathrm{m})$, mean fruit mass ( $g$ fruit ${ }^{-1}$ ), number of fruits per plant, total yield $\left(\mathrm{t} \mathrm{ha}^{-1}\right)$, commercial yield $\left(\mathrm{t} \mathrm{ha} \mathrm{a}^{-1}\right)$ and water use efficiency $\left(\mathrm{kg} \mathrm{m}^{-3}\right)$ for tomato.

\begin{tabular}{|c|c|c|c|c|c|c|c|}
\hline \multirow{2}{*}{$\begin{array}{c}\text { Source } \\
\text { of variation }\end{array}$} & \multirow{2}{*}{ G.L. } & \multicolumn{6}{|c|}{ Mean squares } \\
\hline & & Plant height & Mean fruit mass & Number of fruits & Total yield & Commercial yield & Water use efficiency \\
\hline Soil mulch (SM) & 1 & $0.0020 \mathrm{~ns}$ & $219.9289^{*}$ & $592.2733^{* *}$ & $56.4001^{* *}$ & $157.2098^{* *}$ & $0.5725^{n s}$ \\
\hline Depth water (DW) & 1 & $0.0008 \mathrm{~ns}$ & $1.0678^{\mathrm{ns}}$ & $605.4880^{* *}$ & $165.0368^{* *}$ & $342.5584^{* *}$ & $67.9525^{\mathrm{ns}}$ \\
\hline $\mathrm{SM} \times \mathrm{DW}=164 \mathrm{~mm}$ & 1 & - & - & - & $0.4419 \mathrm{~ns}$ & - & - \\
\hline $\mathrm{SM} \times \mathrm{DW}=188 \mathrm{~mm}$ & 1 & - & - & - & $99.1232^{* *}$ & - & - \\
\hline DW $\times$ With mulch & 1 & - & - & - & $188.5034^{* *}$ & - & - \\
\hline Error & 32 & 0.0021 & 41.5170 & 53.9739 & 7.2906 & 18.7364 & 25.7283 \\
\hline Grand means & & 1.11 & 110.79 & 65.85 & 64.08 & 56.33 & 33.08 \\
\hline C. V. (\%) & & 4.20 & 5.82 & 11.16 & 4.21 & 7.68 & 15.33 \\
\hline
\end{tabular}

; ${ }^{*}$ Significant at $1 \%$ and $5 \%$, respectively, by the $\mathrm{F}$ test; ${ }^{\mathrm{ns}}=$ non-significant.

fruits, with an average of 70 fruits per plant, whereas in the soil without mulch was 62 fruits per plant (Table 2). This result is not in agreement with that obtained by Bogiani et al. (2008), which did not find a difference in the number of fruits per area when the tomato was cultivated in soil with black and white polyethylene film mulch and without soil mulch.

Under these studied conditions, the tomato could have showed better vegetative development and a larger volume of roots in treatments with soil mulch, which resulted in a greater number of fruits per plant and hence higher yield per plant. Water depths also interfered in the number of fruits per plant, with the water depth of $188 \mathrm{~mm}$ producing an average of 68 fruits (Table 3). This result differed from that obtained by Campagnol et al. (2014), which observed that the use of soil plastic mulch and variation of the applied water depths did not influence the number of fruits per plant on the San Vito hybrid, with an average of 45 fruits, lower than the obtained in this study.

Interaction between soil mulch and applied water depth was observed for total tomato yield (Table 1). The highest total yield obtained was when the soil had plastic mulch and water depth of $188 \mathrm{~mm}$ (Table 4). In the treatments without mulch, no effect of the applied water depths was observed.

Ngouajio et al. (2007) obtained yield of $106.5 \mathrm{t} \mathrm{ha}^{-1}$ for tomato cultivated under black plastic film and irrigated since transplanting. Branco et al. (2010) evaluated the productivity

Table 2. Means for commercial yield ( $t$ ha $^{-1}$ ), number of fruits per plant, mean fruit mass ( $g$ fruit ${ }^{-1}$ ) for tomato in the soil with and without mulch.

\begin{tabular}{lcc}
\hline \multicolumn{1}{c}{ Variables response } & With mulch & Without mulch \\
\hline Commercial yield & $58.42 \mathrm{a}$ & $54.24 \mathrm{~b}$ \\
Number of fruits per plant & $70.00 \mathrm{a}$ & $62.00 \mathrm{~b}$ \\
Mean fruit mass & $108.32 \mathrm{~b}$ & $113.26 \mathrm{a}$ \\
\hline
\end{tabular}

Means followed by the same letter do not differ among themselves by $F$ test ( $p \geq 0.05$ ).

Table 3. Means of commercial yield ( $t \mathrm{ha}^{-1}$ ) and number of fruits per plant for tomato under two water depths.

\begin{tabular}{lcc}
\hline \multicolumn{1}{c}{ Variables response } & $\begin{array}{c}\text { Water depth }=164 \\
\mathrm{~mm}\end{array}$ & $\begin{array}{c}\text { Water depth }=188 \\
\mathrm{~mm}\end{array}$ \\
\hline Commercial yield & $53.24 \mathrm{~b}$ & $59.41 \mathrm{a}$ \\
Number of fruits per plant & $62.00 \mathrm{~b}$ & $68.00 \mathrm{a}$ \\
\hline
\end{tabular}

Means followed by the same letter do not differ among themselves by $F$ test ( $p \geq 0.05$ ).
Table 4. Means of total yield ( $t \mathrm{ha}^{-1}$ ) of tomato in the soil with and without mulch and under two water depths.

\begin{tabular}{lcc}
\hline & \multicolumn{2}{c}{ Total yield } \\
\cline { 2 - 3 } & Water depth $=164 \mathrm{~mm}$ & Water depth $=188 \mathrm{~mm}$ \\
\hline With mulch & $62.09 \mathrm{aB}$ & $68.57 \mathrm{aA}$ \\
Without mulch & $61.78 \mathrm{aA}$ & $63.87 \mathrm{bA}$ \\
\hline
\end{tabular}

Means followed by the lowercase letters in the columns and uppercase in lines not differ by $F$ test $(p \geq 0.05)$.

performance of the tomato in different environments and observed that the tomato was more productive in the mulching, regardless of the irrigation system used. Campagnol et al. (2014) verified that the use of plastic mulch increased tomato yield, hybrid "San Vito", at $11.75 \%$ when compared to fruits grown without mulch.

The commercial yield of the tomato was influenced both by mulch soil and by the variation water depths (Table 1), and the soil with mulch provided the largest commercial yield with an mean of $58.42 \mathrm{t} \mathrm{ha}^{-1}$ (Table 2). The increase in commercial yield with the use of plastic mulch was also reported by Campagnol et al. (2014). The authors observed that the soil plastic mulch increased the total and commercial yield of the tomato for the San Vito hybrid. On the other hand, in a study held by Bogiani et al. (2008), the soil mulch with both white and black plastic did not affect the average yield of "Duradoro" tomato.

In relation to the applied water depths, the $188 \mathrm{~mm}$ one achieved the highest commercial yield of the tomato, with an mean of $59.41 \mathrm{tha}^{-1}$ (Table 3). The increase in commercial yield due to higher water depths was also observed by Macêdo \& Alvarenga (2005). The authors verified that the commercial fruits of the tomato, hybrid "Bônus F1" in greenhouse, escalated when an increase occurred in the water depths. On the other hand, in a study conducted by Monte et al. (2013), who studied cv. "Débora" under different water depths (40, $60,80,100$ e $120 \%$ ETc), no difference was observed in the commercial yield of the tomato.

There was no effect of the soil plastic mulch neither of the applied water depths in the water use efficiency (Table 1), with an mean of $33.08 \mathrm{~kg} \mathrm{~m}^{-3}$. This result is not in agreement with the study of Campagnol et al. (2014), who evaluated the water use efficiency in the "San Vito" hybrid under different water depths $(60,80,100,120140 \% \mathrm{Kc})$ and observed that 
the reduction in the water depth associated to the use of black plastic film raised water use efficiency in tomato, with a maximum value of $39.34 \mathrm{~kg} \mathrm{~m}^{-3}$ in treatments with plastic mulch and $60 \%$ Kc water depth. Kalangu et al. (2012) also observed higher water use efficiency when smaller water depths were applied in the tomato "Débora plus" in greenhouse, the maximum water use efficiency $\left(12.40 \mathrm{~kg} \mathrm{~m}^{-3}\right)$ was obtained when the water depth replacement corresponded to $75 \%$ ETc.

The use of soil plastic mulch associated with applied water depth of $188 \mathrm{~mm}$ provided a higher number of fruits per plant and hence a higher commercial yield of the tomato. The average of the total yield was $64.08 \mathrm{tha}^{-1}$, close to the national average for the year 2015, which was $65.87 \mathrm{t} \mathrm{ha}^{-1}$ (IBGE 2016).

\section{Conclusions}

The soil plastic mulch increased the total and commercial yield, the number of fruits per plant; however, it did not influence plant height or water use efficiency. The application of water depth of $188 \mathrm{~mm}$ provided an increase in total and commercial yield and number of fruits per plant, but did not interfere in plant height, mean fruit mass, and water use efficiency. The association of the use plastic mulch and 188 $\mathrm{mm}$ water depth provided a higher total tomato yield in a commercial field.

\section{Acknowledgements}

The authors thank the following institutions: FAPEMIG, CNPq, CAPES and UFLA. In addition, the company Zé Amparo Zil Comércio de Tomates.

\section{Literature Cited}

Almeida, W. F.; Lima, L. A.; Pereira, G. M. Drip pulsed and soil mulching effect on american crisphead lettuce yield. Engenharia Agrícola, v.35, n.6, p.1009-1018, 2015. https://doi.org/10.1590/18094430-Eng.Agric.v35n6p1009-1018/2015.

Alvarenga, M. A. R.; Melo, P. C. T.; Shirahige, F. H. Cultivares. In: Alvarenga, M. A. R. (Ed.). Tomate: produção em campo, casa de vegetação e hidroponia. Lavras: Editora Universitária de Lavras, 2013. p. 39-62.

Alvares, C. A.; Stape, J. L.; Sentelhas, P. C.; Gonçalves, J. L. M.; Sparovek, G. Köpen's climate classification map for Brazil. Meteorologishe Zeitschrift, v.22, n.6, p.711-728, 2013. https:// doi.org/10.1127/0941-2948/2013/0507.

Bogiani, J. C.; Anton, C. S.; Seleguini, A.; Faria Júnior, M. J. A.; Seno, S. Poda apical, densidade de plantas e cobertura plástica do solo nan produtividade do tomateiro em cultivo protegido. Bragantia, v.67, n.1, p.145-151, 2008. https://doi.org/10.1590/S000687052008000100018.

Branco, R. B. F.; Santos, L. G. C.; Goto, R.; Ishimura, I.; Schickmann, S.; Chiarati, C. S. Cultivo orgânico sequencial de hortaliças com dois sistemas de irrigação e duas coberturas de solo. Horticultura Brasileira, v.28, n.1, p.75-80, 2010. https://doi.org/10.1590/ S0102-05362010000100014.
Campagnol, R.; Abrahão, C.; Mello, S. C.; Oviedo, V. R. S.; Minami, K. Impactos do nível de irrigação e da cobertura do solo na cultura do tomateiro. Irriga, v.19, n.3, p.345-357, 2014. https://doi. org/10.15809/irriga.2014v19n3p345.

Elsayed-Farag, S.; Anciso, J.; Marconi, C.; Avila, C.; Rodriguez, A.; Badillo-Vargas, I. E.; Enciso, J. Appropriate planting dates and plastic mulch for increasing common tomato varieties yirld in South Texas. African Journal of Agricultural Research, v.13, n.25, p.1349-1357, 2018. https://doi.org/10.5897/ AJAR2018.13212.

Food and Agriculture Organization of the United Nations - FAO. Crops. http://www.fao.org/faostat/en/\#data/QC. 04 Jan. 2017.

Frizzone, J. A.; Freitas, P. S. L.; Rezende, R.; Faria, M. A. Microirrigação: gotejamento e microaspersão. Maringá: Eduem, 2012. 356p.

Instituto Brasileiro de Geografia e Estatística - IBGE. Levantamento Sistemático de Produção Agrícola: pesquisa mensal de prevençãoe acompanhamento das safras agrícolas no ano civil. Levantamento Sistemático de Produção Agrícola, v.29, n.11, p.1-82, 2016. ftp:// ftp.ibge.gov.br/Producao_Agricola/Levantamento_Sistematico_ da_Producao_Agricola_\%5Bmensal\%5D/Fasciculo/2016/ Ispa_201611.pdf. 20 Jan. 2017.

Macêdo, L. S.; Alvarenga, M. A. R. Efeitos de lâminas de água e fertirrigação potássica sobre o crescimento, produção e qualidade do tomate em ambiente protegido. Ciência e Agrotecnologia, v.29, n.2, p.296-304, 2005. https://doi.org/10.1590/S141370542005000200005.

Marouelli, W. A.; Silva, W. L. C. Tomateiro para processamento industrial: irrigação e fertirrigação por gotejamento. Brasília: Embrapa Hortaliças, 2002. 32p. (Embrapa Hortaliças. Circular Técnica, 30). https://www.embrapa.br/hortalicas/ busca-de-publicacoes/-/publicacao/773410/tomateiropara-processamento-industrial-irrigacao-e-fertirrigacao-porgotejamento. 18 Jul. 2017.

Monte, J. A.; Carvalho, D. F.; Medici, L. O.; Silva, L. D. B.; Pimentel, C. Growth analysis and yield of tomato crop under different irrigation depths. Engenharia Agrícola e Ambiental, v.17, n.9, p.26-931, 2013. https://doi.org/10.1590/S1415-43662013000900003.

Monteiro, C. S.; Balbi, M. E.; Miguel, O. G.; Penteado, P. T. P. S.; Haracemiv, S. M. C. Qualidade nutricional e antioxidante do tomate "Tipo Italiano". Alimentos e Nutrição, v.19, n.1, p.5-31, 2008. http://serv-bib.fcfar.unesp.br/seer/index.php/alimentos/ article/view/196/201. 23 Feb. 2017.

Morais, E. R. C.; Maia, C. E.; Negreiros, M. Z.; Araújo Junior, B. B.; Medeiros, J. F. Crescimento e produtividade do meloeiro Goldex influenciado pela cobertura do solo. Scientia Agraria, v.9, n.2, p. 129-137, 2008. https://doi.org/10.5380/rsa.v9i2.10940.

Ngouajio, M.; Wang, G.; Goldy, R. Withholding of drip irrigation between transplanting and flowering increases the yield of field-grown tomato under plastic mulch. Agricultural Water Management, v.87, n.3, p.285-291, 2007. https://doi. org/10.1016/j.agwat.2006.07.007.

Sampaio, R. A.; Araújo, W. F. Importância da cobertura plástica do solo sobre o cultivo de hortaliças. Agropecuária Técnica, v.22, p.1-12, 2001. 
Soil Survey Staff. Keys to soil taxonomy. 12.ed. Washington: United States Department of Agriculture, Natural Resources Conservation Service, 2014. 360p. https://www.nrcs. usda.gov/wps/portal/nrcs/detail/soils/survey/class/ taxonomy/?cid=nrcs142p2_053580. 19 Mar. 2019.

Van Genuchten, M. T. A closed form equation for predicting the hydraulic conductivity of unsaturated soils. Soil Science Society of America Journal, v.44, n.5, p.892-898, 1980. https://doi. org/10.2136/sssaj1980.03615995004400050002x.
Yuri, J. E.; Resende, G. M.; Costa, N. D.; Mota, J. H. Cultivo de morangueiro sob diferentes tipos de mulching. Horticultura Brasileira, v.30, n.3, p.424-427, 2012. https://doi.org/10.1590/ S0102-05362012000300011.

Zhang, H.; Xiong, Y.; Huang, G.; Xu, X.; Huang, Q. Effect of water stress on processing tomatoes yield, quality and water use efficiency with plastic mulched drip irrigation in Sandy soil of the Hetao Irrigation District. Agricultural Water Management, v.179, p.205214, 2016. https://doi.org/10.1016/j.agwat.2016.07.022. 